\title{
Job-Characteristics Dimensions and Employee Continuance Commitment
}

\author{
Umukoro, J. E. Egwakhe, A. J \\ School of Management Sciences, Babcock University, Ilishan-Remo, Ogun State, Nigeria
}

\begin{abstract}
Effort towards retaining committed of regular non-academic staff has remained a recurrent concern, indicating that, employees' commitment among university workers, could have been compromised. However, even when investigated into, more extrinsic and less intrinsic factors are applied to determine the commitment. Hence, the study approached this gap from job-characteristics dimensions to employee continuance commitment. The crosssectional survey research design was adopted and, data collected from 377 regular non-academic staff using validated and reliable copies of a questionnaire. Multiple regression analysis was applied as the inferential statistics. Results from multiple regression analysis conducted found that job-characteristics dimensions had a significant effect on employee continuance commitment $\left[\mathrm{R}=0.726, \mathrm{~F}_{(5,371)}=78.081, \mathrm{p}<0.05\right]$. Also, task identity, task significance, and feedback had a significant positive effect on continuance commitment. On the strength of the statistical findings, it was recommended for management emphasize on task identify, significance and, feedback to enable continuance commitment of non-academic staff.
\end{abstract}

Keywords: Continuance commitment, job-characteristics dimensions,

DOI: $10.7176 / \mathrm{EJBM} / 11-27-03$

Publication date:September $30^{\text {th }} 2019$

\section{Introduction}

Continuance commitment commentary has engendered several debates as to whether employees stay and perform optimally in an organization as a result of intrinsic and or extrinsic factors. Interestingly, the uniqueness, dynamism, and complexity of man are unfathomable and unpredictable, and the same can equally refer to what triggers an individual's commitment (Brumley, 2014). Globally, academics, business operators, and administrators for over a decade, are increasingly acknowledging employees' commitment as a factor in attaining organizational goals (Nzewi, Chiekezie, Ekene, Raphael, \& Ebuka, 2017; Shahid \& Azhar, 2013). However, context observations and workplace practices within and among different industries have hybridized to depict commitment problems as turnover, absenteeism and sub-optimal performance (Ebeh, Uhiara, Sydney-Agbor, \& Nwankwo, 2013; Gupta, Shaheen, \& Reddy, 2017).

According to Allen and Meyer (1990), continuance commitment is based on the costs that employees associate with leaving the organization, and it could be dependent on extrinsic and or intrinsic factors. Mouhamadou, Peter, and Moussa (2016) noted that continuance commitment occurs when employees stay in the organization because of the recognition of the costs associated with leaving the organization. Therefore, the economic cost of leaving the organization could predict continuance commitment. Nevertheless, Allen and Meyer (1991) claimed that continuance commitment could be influenced either by monetary rewards (Aina, Adeyeye, \& Ige, 2012), structure (Ardrey, Pecotich, \& Ungar, 2001), withdrawal intentions (Ortiz \& Lau, 2011), and or human resource management practices (Shahid \& Azhar, 2013). However, Ebeh, Uhiara, Sydney-Agbor, and Nwankwo (2013) argued that, employee commitment may not only be as a result of the organization type and benefits but, the inherent characteristics of the job such as aspects of the task the employee is engaged in, the degree to which the job is defined and is under the control of the employee.

Job characteristics also referred to as job enrichment or job design (Magaji, Akpa, \& Akinlabi, 2017; Salau, Adeniji \& Oyewunmi, 2014), allows employees more control and responsibility for how their job is performed subject to knowledge, skills and ability (Egwakhe, 2014). Thus, achieving job characteristics involve redesigning of jobs in a way that increases the opportunities for an employee to experience feelings of responsibility, achievement, growth, recognition, autonomy, the significance of the job, feedback in the work setting and having better control (Magaji, 2015). However, Akeke, Akeke, and Awolusi (2015) and Herzberg (1959) claimed that every job must have five core dimensions which are, skill variety, task significance, task identity, autonomy, and feedback to achieve job characteristics.

Contextually, though many institutions, including educational institutions' assertion are that employees are their greatest asset and agents of success, the notion of employee continuance commitment, which is a dimension of commitment is often overlooked. Also, the lack of commitment to work has remained one of the quality values deficient among most personnel in higher educational institutions (Egwakhe \& Osabuohien, 2009; Kiiza \& Picho, 2015). Reports of nonchalant attitude to work, laxity, mediocrity, and ineptitude reigns highly among most staff members in Nigerian universities (Akinsanya \& Oludeyi, 2013; Oludeyi, 2015). The problem becomes more worrisome as reports of issuance of certificates with incorrect biodata, missing scores, upgrading of failed 
grades at result computation level, hiding failed grades and selling of grades, is on the increase (Amune, 2015; Asiyai, 2015). Such attitude could have contributed to the reported fall in the standard of education and rapid knowledge declination currently experienced among Nigerians (Nigerian Institute of Personnel Management, 2012; Okebukola, 2015; Okojie, 2016; Oludeyi, 2015; Philips Consulting, 2014).

Regrettably, studies have shown that similar crisis earlier highlighted is gradually creeping into the operations in private universities (Amponsah \& Onuoha, 2015; Magaji, Akpa, \& Akinlabi, 2017; Oludeyi, 2015). Consequently, since several studies conducted on employee commitment in various sectors have applied extrinsic factors such as reward and benefits, salary, training and development, and promotion (Aina, Adeyeye, \& Ige, 2012; Oyelere, Opute, \& Akinsowon, 2015; Umoh, Mamn, \& Mnim, 2014); researchers have demonstrated the need for more studies on employee commitment using intrinsic factors such as, job characteristics (Awolusi, 2013; Magaji, 2015; Oludeyi, 2015), in universities and other sectors. Hence establishing scope and unit of analysis gaps. It is on this premise that this work investigated whether job characteristics dimensions could affect employee continuance commitment in selected private universities in Ogun State Nigerian. The work is organized into a literature review after the introduction, methodology, presentation of results, conclusion, and recommendation.

\section{Literature Review}

Conceptually, Stebbins (1970) and Wang, Indridasson, and Saunders (2011) referred to continuance commitment as what is preventing a person from changing to another. Zopiatis, Constanti, and Theocharous (2014) described continuance commitment as a psychological state that is different from value commitment since it is not as a result of the presence of rewards rather, it is from the presence of penalties which are associated with leaving a position. Oludeyi (2015) affirmed that continuance commitment had been shown to affect individuals' intention to keep their position and stay as a part of a project or organization as, Enyia (2016) noted that people have the knowledge of the economic concerns associated when leaving a position or organization. Umoh et al. (2014) argued that, as against the submission of Stebbins (1970), the costs associated with leaving an organization might include a wide variety of entities, some of which are measurable and others which are more intangible. Hence continuance commitment could develop out of the perceived cost (benefit against loss), and requires that the employee should be aware of these benefits and losses.

Job characteristics involve ensuring that a job is designed to motivate and enhance performance (Magaji, 2015). Salau et al. (2014) claimed that job characteristics is a design of job that increases the volume of employees' autonomy, control, skill varieties and responsibility which invariably helps to reduce rigidity, tediousness, and lack of creativity. Davoudi and Mehdi (2013) proposed job characteristics as 'vertical loading' of a job implying that an enriched task which depicts the character of the job should provide a range of tasks to be carried out with an adequate feedback mechanism, encouragement, and communication. As a result, job characteristics allows the employee to work innovatively and accordingly because of the expansion of role and responsibility (Obi-Nwosu, Chiamaka, \& Tochukwu, 2013). However, Hackman and Oldham (1975) posited that variety, autonomy and decision authority are three ways of adding challenge to a job, while job enrichment and job rotation are the two ways of adding variety and challenge. Thus Vijay and Indradevi (2015) asserted that for a task to be referred to as enriched it should have the five job enrichment dimensions which include: skill variety, task identity, task significance, autonomy, and feedback.

\subsection{Skill variety}

Skill variety refers to the degree to which the job requires different skills and talents. Derek and Laura (2000) opined that movement of employees from one task to another within a particular organization and allowing workers to adopt a variability of tasks in their work helps in avoiding repetitiveness, dullness, and boredom. Several researchers have claimed that when a variety of skills are necessary to complete a task and those skills are perceived to be of value to the organization; employees find their work to be more meaningful (Bratton, 2007; Magaji, 2015). As a result, an employee can draw from several different skills and abilities as well as upon a range of knowledge (Ali \& Aroosiya, 2010). Thus, whereas a job that has limited skill variety is likely to be less stimulating and may result in boredom, jobs that are high in skill variety are perceived by employees as more challenging because of the range of skills involved (Kemboi, Biwott, Chenuos, \& Rutto, 2013; Pee, 2011). However, very high skill variety may deplete employees' mental resources and lead to mental overload and increase job pressure (Chen \& Chiu 2009). The above assertions were corroborated by Awolusi (2015) that despite the advantages of skill variety, the strategies implemented in achieving skill variety have to be prudently weighed.

\subsection{Task Identity}

According to Choge, Chepkiyeng, and Chelimo (2014), task identity is defined as the extent to which an individual can complete a whole and identifiable piece of work. Scholars have opined that employees who work 
on a tiny part of whole work are unable to identify their contribution to the task, however, when tasks are broadened to produce a whole product or an identifiable part of it, then task identity has been established (Hasebur \& Sheikh, 2014; Lunenburg, 2013). Lunenburg (2013) indicated that task identity creates a sense of responsibility for completion that acts as a motivational driver and increased commitment. Omid and Alborz (2014) added that it assists employees in understanding the link between the jobs assigned to them and other activities in the organization. As a result, task identity is a critical element of employee personal and workout outcomes since the entire job is viewed from a holistic view and not viewed for its components (Nyabundi \& Kagiri, 2016). Thus employees working in jobs with low task identity feel that they lack personal accomplishment, feel bored, and perceive their jobs as meaningless (Nyabundi, \& Kagiri, 2016; Pee, 2011). However, when task identity is very high, employees are likely to feel solely accountable for the results of their work and this may result in stress and negatively impact commitment (Pee, 2011; Nyabundi \& Kagiri, 2016).

\subsection{Task Significance}

Scholars defined task significance as the degree to which the job has a substantial impact on the lives or work of other people, both in the immediate organization or in the external environment (Choge, Chepkiyeng, \& Chelimo, 2014; Lunenburg, 2013). Academics have claimed that if employees understand the significance of their tasks, they will seek to increase their capabilities and learning. Such individuals continually desire to improve their work knowledge to maintain the value of their job. (Omid \& Alborz, 2015). Consequently, Salau et al. (2014) asserted that task significance centers on how essential the task is to the overall efforts of the organization both locally and internationally. Hence, when task significance is very high, it will serve as a driving force and motivational tool for employees to increase and exert more efforts on the job (Lynton \& Pareek, 2000). Accordingly, Fourman and Jones (1997) submits that familiarization of the workers with how different fragment of the organization works collectively, be aware of what the end product is, what it does and who uses it, since an organization is a "system" that depends on the performance of each segment operated by various employees is paramount.

\subsection{Autonomy}

Sisodia and Das (2013) defined job autonomy as the extent to which employees have a say in scheduling their work, selecting the equipment to be used, and deciding on procedures to be followed. Several scholars have claimed that job autonomy refers to the extent to which an employee can determine the pace, sequence, and methods to accomplish the job (Magaji, 2015; Naqvi, Ishtiaq, Kanwal, \& Ali, 2013; Volmer, Spurk, \& Niessen, 2012). Salau et al. (2014) claimed that autonomy reflects the degree of liberty, freedom, independence, impartiality, objectivity, and administrative ability the employee has in completing the task assigned. Hence, increased job autonomy enables employees to break out of a routine and to find the best solution, gives employees the opportunity to try out new and useful combinations of work procedures (Wang, Lin, \& Chu, 2011). However, some scholars argued that job autonomy is different from freedom; as the latter refers to people's opportunities to make a judgement at work and to choose which tasks to accomplish (Cohen-Meitar, Carmeli, \& Waldman, 2009; Naqvi et al., 2013). Nevertheless, whether autonomy or freedom, Volmer et al. (2012) claimed that employees have many more opportunities provided by job characteristics to develop new and useful ideas and to demonstrate originality at work.

\subsection{Feedback}

Hellriegel and Slocum (2011) opined that job feedback is the degree to which carrying out the work activities required by the job provides the individual with direction and clear information about the effectiveness of the individual's performance. However, feedback can be positive or negative, but it is best when it is balanced appropriately (Lunenburg, 2013). As a result, feedback should frequently occur rather than be delayed until the annual evaluation meeting. Sole (2009) claimed that feedback does not stop until it goes further to communicate back to the employees. Employee's evaluation through appropriate feedback mechanism to a considerable extent help employees to monitor progress within the organization to carry out duties, tasks, and responsibilities and this feedback can be made available on a daily, weekly, monthly, and quarterly basis (Kemboi et al., 2013). Therefore, Salau et al. (2014) affirmed that feedback in return should not just be every year but also as frequent and timely as possible to maintain and sustain performance and measure commitment. However, whereas too much feedback may have a negative effect, too much negative feedback can threaten an employees' sense of competence while too much positive feedback can cause an employee to feel ingratiated (Kemboi et al., 2013).

Empirically, previous studies have provided evidence of strong correlations between dimensions of job characteristics and the commitment of employees (Don-Solomon \& Luke, 2016; Volmer et al., 2012). Other studies found that employees, who are more productive and can stay longer on the job, were able to highlight higher commitment ratings as a result of job satisfaction and job design (Azeez et al., 2016; Velnampy \& Sivesan, 2012). However, some studies provided evidence of only a few dimensions of job characteristics 
significantly related to the commitment of employees' dependent on the type of organization, type of job, and position (Kónya, Matić, \& Pavlović, 2016); as studies have shown that a low commitment has is associated with low levels of morale (Fika, Ibi, \& Abdulrahman, 2016; Ushie, Agba, \& Okorie, 2015).

Further, previous studies have shown that employees working in jobs with high task significance believe that their actions benefit others (social impact) and valued by others (social worth) (Grant 2008; Salau et al., 2014). In line with these findings, Pee (2011) found that task significance is positively related to employee commitment; while high levels of job control and autonomy are negatively linked to role conflict and role ambiguity (Spector, 1986). Conversely, employees with less job autonomy have only pre-defined strategies to fulfill tasks (Humphrey et al., 2007). Saragih (2011) added that previous researches have used job autonomy to predict and test the effects of job design on work outcomes and found a consistent positive relationship between job autonomy and work outcomes. However, research on job autonomy has left several questions unanswered. Further, Salau et al. (2014) postulated that several researchers have submitted that, the use of skill variety serves as a means of retaining, motivating, enhancing and sustaining commitment in workers (Davoudi \& Mehdi, 2013; Fourman \& Jones, 1997). Noor Harun (2010) found that work-related variables such as role clarity, job autonomy, and feedback, all were found to be correlates of employee commitment.

Theoretically, the Two-Factor Theory (T-FT) by Frederick Herzberg in 1959 and Job Characteristic Model (JCM) by Hackman and Oldham in 1976 focused on job characteristics variable. While the Two-Dimensional Commitment Theory by Cohen (2007) focused on commitment. The theories proposed that some factors in the workplace cause job satisfaction, while a separate set of factors cause dissatisfaction. That, often, work should be arranged as job enlargement, rotation and or enrichment to create the opportunity for employees to take part in planning, performing, and evaluating their work. Also that removing some of the control management has over employees and increasing the accountability and responsibility workers have over their work would eventually, increase employee autonomy. Further, an individual's intentions and general perceptions of commitment were developed in the socialization process and were influenced by personal beliefs, values, expectations about the job and prior experiences before entry into the organization since, socialization is mostly influenced outside work (pre-entry into institution) (WeiBo, Kaur, \& Jun 2010). Inferring that as a result of the personality and socialization process of an individual, whereas skill variety, task identity, task significance, autonomy, and feedback could have a positive and significant effect on continuance commitment for an employee it may not be the same for another employee.

\section{Methodology}

This work adopted the cross-sectional survey research design to attempt to understand a particular population at a time and to ensure that the amount of uncertainty characterizing a decision in a situation is clearly defined through highly structured approach (Zikmund, Babin, Carr, \& Griffin, 2012). The decision to use cross-sectional survey is consistent with the study of Onabajo (2011) and Oyelere et al., (2015) which focused on organizational commitment among employees of Nigerian public sector as a developing nation perspective. Bell-Ellis, Jones, and Longstreth (2015) applied similar design to determine, spirit at work in faculty and staff organizational commitment among secular and faith-based employees in selected universities in the United States. While Magaji, Akpa, and Akinlabi (2017) assessed the effect of job enrichment on employee commitment. The study was conducted in Ogun State since the State has the highest number of private universities in Nigeria (NUC, 2018), as there are twelve (12) private universities.

Six (6) private universities was selected for proportionate distribution. The six (6) private universities were selected based on year of establishment (accredited universities from 5 years and above - 1999 to 2012), and ranking on JAMB's 2017 statistics, which considered academic stability, popularity, affordability, available facilities and quality of academic/non-academic staff in determining applicants' choice of preferred universities as gathered by the Economic Confidential, 2017. The selected private universities were, Covenant University in Ota (ranked $1^{\text {st }}$ ), Babcock University in Ilshan-Remo (ranked 2 ${ }^{\text {nd }}$ ), Bells University in Ota (ranked 20 ${ }^{\text {th }}$ ), Crescent University in Abeokuta (ranked 35 ${ }^{\text {th }}$ ), Crawford University in Igbesa (ranked $36^{\text {th }}$ ) and McPherson University in Sotayo, Seriki (ranked 41 ${ }^{\text {st }}$ ), Ogun State, Nigeria. The target population consisted of 2,604 regular non-academic staff as of January 2018 (Administrative offices of the selected private universities Human Resource, 2018).

A sample size of four hundred and thirty (430) constituted the sample size determined by utilizing the formula developed by Krejcie and Morgan (1970) for sample determination for a finite population. The study adopted a multiple-stage sampling technique. The research was conducted through a well-structured questionnaire from regular non-academic staff to obtain large amounts of data needed from a large number of people in a short period, to quantified data to compare and contrast other researches, to measure change, and add to empirics. Items in the questionnaire were adopted and adapted because the questionnaire have been used in different countries and industries.

The pilot test conducted was on the questionnaire along with validity and the reliability test. Content, criterion, and construct validity were established (Fornell \& Larcker, 1981) to determine the reliability of the 
instrument. The face content or face validity (scale's validity) was applied to measure how well the content of the research measurement instrument measures what it is designed to measure. The construct validity was addressed through the review of literature; adopting and adapting instruments used in previous research that has been critically reviewed and validated (Skill Variety $(\alpha)=0.71$, Task Identity $(\alpha)=0.89$, Task Significance $(\alpha)=$ 0.86, Autonomy $(\alpha)=0.79$, Feedback $(\alpha)=0.71$, and Continuance Commitment $(\alpha)=0.73$ ) (Allen $\&$ Meyer, 1990; Hackman \& Oldham, 1975; Morgeson \& Humphrey, 2006). While the criterion validity was used to measure the ability of the research instrument to predict future outcomes. The reliability result through Cronbach's alpha coefficient from the internal consistency test revealed $(\alpha)=0.871$ (with the lowest being 0.723 ; and the highest 0.895). Based on the results of the pre-test result as depicted by the Cronbach's alpha that was greater than $(>) 0.70$ and closer to 1.0 (Livingston, 2018; Nunnally, 1978), the structured questionnaire was considered reliable. The work used primary data sourced from the sampled private universities and analyzed by using descriptive and inferential statistics through Statistical Package for Service Solutions SPSS 21.0. The research model framework reviewed the variables in this work on the effect and relationship between the independent and dependent variables. In light of the model, the multiple regression equation was established based on the dimensions of job characteristics. Hence the model was formulated about the research objective as stated below:

$\mathrm{Y}=\mathrm{f}(\mathrm{X})$

Where:

$\mathrm{Y}=$ Employee Continuance Commitment (ECC)

$\mathrm{X}=$ Job Characteristics Dimensions (JCD)

Where: $\quad \mathrm{x}_{1}=$ Skill Variety $(\mathrm{SV})$

$\mathrm{x}_{2}=$ Task Identity (TI)

$\mathrm{x}_{3}=$ Task Significance $(\mathrm{TS})$

$\mathrm{x}_{4}=$ Autonomy $(\mathrm{AT})$

$\mathrm{x}_{5}=$ Feedback $(\mathrm{FB})$

The functional relationship of the model is presented as:

$\Sigma \mathrm{SV}+\mathrm{TI}+\mathrm{TS}+\mathrm{AT}+\mathrm{FB}=\mathrm{JCD}$ Hence

$\mathrm{ECC}=\mathrm{a}_{0}+\beta_{1} \mathrm{SV}_{\mathrm{i}}+\beta_{2} \mathrm{TI}_{\mathrm{i}}+\beta_{3} \mathrm{TS}_{\mathrm{i}}+\beta_{4} \mathrm{AT}_{\mathrm{i}}+\beta_{5} \mathrm{FB}_{\mathrm{i}}+\mu \mathrm{i}$

Where: $\quad \beta_{0}=$ Constant term

$\beta_{1}=$ Coefficient of skill variety

$\beta_{2}=$ Coefficient of task identity

$\beta_{3}=$ Coefficient of task significance

$\beta_{3}=$ Coefficient of autonomy

$\beta_{3}=$ Coefficient of feedback

$\mu=$ Error term (Stochastic variable).

The multiple regression analysis was used to test the hypothesis at $95 \%$ confidence interval.

\section{Results and Discussions}

The retrieved copies from the administered four hundred and thirty (430) questionnaires was three hundred and seventy-seven (377) which represented a response rate of $87.7 \%$, The study assumption was that, jobcharacteristics dimensions (skill variety, task identity, task significance, autonomy, feedback) have no significant effect on employee continuance commitment. Therefore, to test the formulated hypothesis, a multiple regression analysis was done by the researcher, as presented in Table 4.1. 
Table 4.1: Summary of evaluation statistics of multiple regression analysis between Job-Characteristics Dimensions and Employee Continuance Commitment

\begin{tabular}{|c|c|c|c|c|c|c|c|}
\hline Variable & $\begin{array}{c}\text { Correlation } \\
\text { Coefficient } \\
\text { (R) }\end{array}$ & $\begin{array}{l}\text { Coefficient of } \\
\text { Determination } \\
\left(\mathbf{R}^{2}\right)\end{array}$ & $\begin{array}{c}\mathbf{P}- \\
\text { value }\end{array}$ & Constant & $\begin{array}{c}\text { Parameter } \\
\text { estimate (B) }\end{array}$ & $\begin{array}{c}\text { T- } \\
\text { value }\end{array}$ & $\begin{array}{c}\text { F- } \\
\text { value }\end{array}$ \\
\hline $\begin{array}{l}\text { Joint Results } \\
\text { (FWB \& SW) }\end{array}$ & $0.716^{\mathrm{a}}$ & 0.513 & 0.000 & \multirow[t]{7}{*}{-.858} & & 2.615 & \multirow[t]{7}{*}{78.081} \\
\hline $\begin{array}{l}\text { Individual } \\
\text { Results }\end{array}$ & Beta & & & & & & \\
\hline Skill Variety & -.088 & & .075 & & -.138 & $\begin{array}{c}- \\
1.783\end{array}$ & \\
\hline Task Identity & .118 & & .023 & & .207 & 2.286 & \\
\hline $\begin{array}{l}\text { Task } \\
\text { Significance }\end{array}$ & .158 & & .004 & & .249 & 2.932 & \\
\hline Autonomy & .119 & & .064 & & .184 & 1.934 & \\
\hline Feedback & .474 & & .000 & & .578 & 8.163 & \\
\hline
\end{tabular}

b. Predictors: (Constant), Job Characteristics (Feedback, Skill Variety, Task Identity, Task Significance, Autonomy)

Source: Field Survey, 2018

Source: Results extracted from Regression tables (see appendix I)

Number of companies: 377

Level of significance $0.05(5 \%)$

Significant at $p<0.05$

\subsection{Interpretation}

The multiple regression aggregate results in Table 4.1 showed that the relationship between job characteristics dimensions (skill variety, task identity, task significance, autonomy, feedback) and employee continuance commitment was strong, positive and statistically significant $\left[\mathrm{R}=0.726, F_{(5,371)}=78.081, p<0.05\right]$. Moreover, the goodness of fit model presented in Table 4.1 shows that with Adjusted $R^{2}=0.506$, implies that about $50.6 \%$ variation in employee continuance commitment is explained by variations in job characteristics dimensions. This relatively high moderate association is attributed to the fact that job characteristics dimensions yielded some equivalent results in terms of employee continuance commitment. However, the model failed to explain $49.4 \%$ of the variation, meaning that there are other factors associated with employee continuance commitment which were not fitted in the model and thus, the study assumption which states that job-characteristics dimensions (skill variety, task identity, task significance, autonomy, feedback) have no significant effect on employee continuance commitment is hereby rejected.

Further, Table 4.1 presents result of individual multiple regression analysis. The results revealed that out of the five job characteristics dimensions, task identity $[\beta=0.118, t=2.286, p=.023]$, task significance $[\beta=0.158$, $t=2.932, p=0.004]$ and feedback $[\beta=0.474, t=8.163, p=0.000]$ have positive and statistically significant effect on employee continuance commitment. Autonomy $[\beta=0.199, t=1.934$, and $p=.064]$ have positive but no significant effect on employee continuance commitment. While skill variety $[\beta=-0.088, t=-1.783$, and $p$ $=.075]$ have negative and no significant effect on employee continuance commitment.

The model equation parameter estimate depicting good fit for Job Characteristics dimensions (skill variety, task identity, task significance, autonomy, and feedback) and Employee Continuance Commitment is, therefore;

$\mathrm{ECC}=-0.858+0.207 \mathrm{TI}+0.249 \mathrm{TS}+0.578 \mathrm{FB}$

Where:

$\mathrm{ECC}=$ Employee Continuance Commitment

$\mathrm{TI}=$ Task Identity

$\mathrm{TS}=$ Task Significance

$\mathrm{FB}=$ Feedback

The regression model equation indicates that $\beta_{0}$ is -0.858 when $X=0$. The value -0.858 implies that statistically without job characteristics dimensions, there seem to be a negative effect on employee continuance commitment. Further, the coefficient (parameter estimate) results indicates that on job characteristics dimensions, for one-unit increase in task identity, task significance, autonomy and feedback; employee continuance commitment increases by $0.207,0.249,0.184,0.578$ units respectively (that is, statistically, employee continuance commitment will increase by $20.7 \%, 24.9 \%, 18.4 \%$, and $57.8 \%$ respectively). Indicting that statistically, based on data retrieved for this study and analyzed, of the five job characteristics dimensions only 
task identity, task significance, and feedback have a positive effect on employee continuance commitment. However, the aggregate result from the multiple regression analysis as earlier stated $\left[\mathrm{R}=0.726, F_{(5,371)}=78.081\right.$, $p<0.05]$ indicates that job characteristics dimensions have a significant effect on employee continuance commitment.

\subsection{Discussion of Findings}

The findings in Tables 4.1 revealed that job-characteristics dimensions (skill variety, task identity, task significance, autonomy, feedback) have a significant effect on employee continuance commitment in selected private universities in Ogun State. Whereas the aggregate result (ANOVA) agreed with the findings from previous studies conducted in universities that, job enrichment is a strong predictor of work-related attitudes as, there is a positive correlation between job depth, core job dimension elements of job enrichment, workers' commitment and performance (Oludeyi, 2015; Salau et al., 2014), there were disparities in the individual regression result (Coefficients). However, Velnampy and Sivesan (2012) claimed that employees who are more productive and stay longer on the job were able to highlight higher commitment ratings as a result of job enrichment. Faraji et al. (2015) affirmed that individual's job characteristics have a positive and significant influence on commitment such that employees' commitment can be increased through redesigning and enriching employees' job.

The individual coefficient results for the study hypothesis revealed that while, skill significance, task identity, and feedback had a positive and significant effect, autonomy and skill variety had no significant effect on employee continuance commitment although, autonomy, had a positive link with employee continuance commitment. Supporting these findings, Magaji (2015) found that employees with greater job autonomy feel responsible for jobs done and perform better when there is freedom, autonomy, and opportunity to decide what and how to perform and accomplish their jobs. Kariuki and Makori (2015) supported the study findings that people whose work is autonomous, experience a feeling of responsibility and are more likely to invest effort into their work, even in the face of obstacles. Nevertheless, though such feelings of self-worth as a result of having autonomy on the job can generate high levels of engagement, having too much autonomy can backfire on commitment (Kariuki \& Makori, 2015). The submissions in this discussion could be the reason, although autonomy had a weak positive relationship, it has no significant effect on employee continuance commitment in this study. It could be that since employees with more continuance commitment focus more on the economic benefits they stand to gain and are less concerned about the freedom the job offers hence they are obligated to stay in the institution.

Further, Bratton (2007) pointed out that when a variety of skills are necessary to complete a task, and those skills are perceived to be of value to the organization, employees find their work to be more meaningful. Aina and Omoniyi (2014) added that one way to achieve task variety is through job rotation that is, moving employees from job to job within the institution, thus allowing employees a variety of tasks in their work and helping to prevent boredom. Magaji (2015) supported Bratton (2007) and Aina and Omoniyi (2014) that, using only one skill to do the same task repeatedly can be boring, typically causing the employee's productivity to decrease after a period. Nevertheless, skill variety does not guarantee continuance commitment. Consequently, since findings in this study revealed that skill variety is not statistically significant on employee continuance commitment, could imply that skill variety will not determine perceived sunk costs (Oludeyi, 2015), as employees with continuance commitment are committed to the job not because of the skill variety required but as a result of either personal investments or what they stand to gain.

Consistent with this study finding is the work by previous scholars that there is a positive relationship between task identity and commitment of employees (Davoudi \& Mehdi, 2013; Lunenburg, 2013; Salau et al. 2014). Further, Steger et al. (2013) found that perceptions on task significance could be enhanced by redesigning work such that it could be manipulated through interactions with people as task significance enables employees job to have a substantial impact on the lives of other people whether inside or outside the organization environment. Also, studies have consistently demonstrated that task significant work is especially meaningful and positively affects commitment (Allan et al., 2014; Nzewi et al., 2017), as high task significance could serve as a driving force and motivational tool to increase and exert more efforts on the job (Lynton \& Pareek, 2000; Omid \& Alborz, 2015).

Additionally, Mone and London (2010) discovered that the absence of feedback mechanism generates job dissatisfaction among employees as the system is seen as ineffective and unfair hence increasing employees desire to leave. Likewise, Lunenburg (2013) affirmed that job feedback give employees knowledge of the actual results of work activities, and such knowledge improves the individuals' effectiveness and continuance commitment. Therefore, Kónya et al. (2016) asserted that job characteristics has a positive effect on the varied dimensions of commitment. More so, according to the Job Characteristic Model (JCM) by Hackman and Oldham (1976), the ability of the person to make a psychological connection with the job defined the influence of the task on the person. Consequently, selected personality characteristics could influence individual perceptions, 
which then determined whether intrinsic aspects of the job would be motivational or not.

\section{Conclusion and Recommendations}

Following the data analyzed and findings established the study results showed that job characteristics dimensions had a statistically significant positive effect on employee continuance commitment. However, the individual coefficient results revealed that out of the five job characteristics dimensions, task identity, task significance, and feedback had a positive and significant effect on employee continuance commitment. Autonomy had positive but was not significant; while skill variety had a negative and no significant effect on employee continuance commitment. On the strength of the statistical findings, it was recommended for management emphasize on task identify, significance and, feedback to enable continuance commitment of non-academic staff. Also, future researchers should extend the study to public universities and academic staff in both private and public universities.

\section{References}

Aina, O. O., \& Omoniyi, A. T. (2014). The effect of job enrichment schemes on selected construction workers in Nigeria, organization. Technology and Management in Construction an International Journal. 933-941.

Aina, S., Adeyeye, F., \& Ige, K. (2012). Organizational culture and employees' commitment in public tertiary institutions in Lagos State, Nigeria. European Journal of Globalization and Development Research, 3(1), 128-142.

Akeke, N. I., Akeke, A. R., \& Awolusi, O. D. (2015). The effect of job satisfaction on organizational commitment among non-academic staff of tertiary institutions in Ekiti State. International Journal of Interdisciplinary Research Method, 2(1), 25-39.

Akinsanya, A. O., \& Oludeyi, O. S. (2013). The dialectics of staff unionism and university management; Critical discourse for effective educational service delivery. National Association for Science, Humanities \& Education Research Journal, 11(2), 65-72.

Ali, H. M., \& Aroosiya, M. (2012). Impact of job design on employees' performance. Journal of Management, $8(1), 33-41$.

Allan, B. A., Autin, K. L, \& Duffy, R. D. (2014). Examining social class and work meaning within the psychology of working framework. The Journal of Career Assessment, 22, 543-561.

Allen, N. J., \& Meyer, J. P. (1990). The measurement and antecedents of affective, continuance and normative commitment. Journal of Occupational Psychology, 63, 1-18.

Amponsah, E. B., \& Onuoha, L. N. (2015). The performance and challenges of private universities in Ghana and Nigeria. International Journal of Business and Social Science. 4(5), 256-263

Amune, J. B. (2015). A comparative study of the relative merits of employee commitment among the academic librarians in Nigerian public and private universities. International Journal of Academic Research in Business \& Social Sciences, 5(5), 1-11.

Ardrey, W. J., Pecotich, A. J., \& Ungar, E. (2001). Structure, commitment and strategic action for Asian transitional nations' financial systems in crisis", International Journal of Bank Marketing, 19(1), 18-37.

Asiyai, R. I. (2015). Challenges of quality higher education in Nigeria in the 21 st century. International Journal of Educational Planning \& Administration, 3(2), 159-172.

Awolusi, O. D. (2013). Effects of motivation on employees' job commitment in the Nigerian banking industry: an empirical analysis. International Journal of Business \& Innovation Research, 1(3), 1-17.

Bell-Ellis, R. S., Jones, L., Longstreth, M., \& Neal, J. (2015). Spirit at work in faculty and staff organizational commitment. Journal of Management, Spirituality and Religion, 12(2), 156-177.

Bratton, J. (2007), “Work and Organizational Behavior”. New York: Paul Grave Mac Millan.

Chen, C. C., \& Chiu, S. F. (2009). The mediating role of job involvement in the relationship between job characteristics and organizational citizenship behavior. The Journal of Social Psychology, 149(4), 474-494.

Choge, P. J., Chepkiyeng, J. F., \& Chelimo, K. K. (2014). Effects of task identity on employee motivation: A survey of Eldoret Polytechnic, Kenya. European Journal of Business and Management. 6(33), 222-283.

Cohen, A. (2007). Commitment before and after: An evaluation and reconceptualization of organizational commitment. Human Resource Management Review, 17, 336-354.

Cohen-Meitar, R., Carmeli, A., \& Waldman, D. A. (2009). Linking meaningfulness in the workplace to employee creativity: the intervening role of organizational identification and positive psychological experiences. Creativity Research Journal, 21(4), 361-375.

Davoudi, M., \& Mehdi, S. (2013). Impact of job enrichment in organizational citizenship behavior. SCMS Journal of Indian Management, 10(2), 106-112.

Don-Solomon, A., \& Luke, G. R. (2016). Job design and employee absenteeism: A case study of some government parastatals in Nigeria. International Journal of Secondary Education. Special Issue: Teaching Methods and Learning Styles in Education, 3(6), 67-71. 
Ebeh, R. E., Uhiara, A. C., Sydney-Agbor, N., \& Nwankwo, B. N. (2013). Demographic and organizational antecedents of commitment among SME employees in Imo State, Nigeria. International Journal of Science and Research, 4(6), 1214-1223.

Economic Confidential. (2017, August 29). Universities rankings-2017. Retrieved from http://www.Economicconfidential.com

Egwakhe, J. A. (2014). Leadership dual behaviour and workers' performance: A people-task orientation model. International Journal of Innovative Research \& Development, 3(4), 184-191.

Egwakhe, J. A., \& Osabuohien, E. S. C. (2009). Educational backgrounds and youth criminality in Nigeria. International Forum, 12(1), 65-79

Enyia, C. D., \& Orokor, L. E. (2016). The role of formal and informal communication in determining employee affective and continuance commitment in oil and gas companies. International Journal of Advanced Academic Research, 2(9), 33-44.

Faraji, O., Ramazani, A. A., Hedaiati, P., Aliabadi, A., Elhamirad, S., \& Valiee, S. (2015). Relationship between job characteristics and organizational commitment: a descriptive analytical study. Iranian Red Crescent Medical Journal, 7(11), 1-11.

Fika, I. B., Ibi, M. B., \& Abdulrahman, A. (2016). Staff utilization and commitment in Borno State colleges of education, Nigeria. Journal of Education \& Practice. 7(20), 68-74.

Fornell, C., \& Larcker, D. F. (1981). Evaluating structural equation models with unobservable variable and measurement error. Journal of Marketing Research, 18(1), 39-50.

Fourman, L. S., \& Jones, J. (1997) Job enrichment in extension. http:// www.joe.org/joe//iw1.php, Accessed on 18th December, 2015.

Grant, A. M. (2008). The significance of task significance: Job performance effects, relational mechanisms, and boundary conditions. Journal of Applied Psychology, 108-124.

Gupta, M., Shaheen, M., \& Reddy, P. K. (2017). Impact of psychological capital on organizational citizenship behavior: Mediation by work engagement. Journal of Management Development, 36(7), 1-25.

Hackman, J. R., \& Oldham, G. R. (1976). Motivating through the design of work: Test of a theory. Organizational Behaviour \& Performance, 16: 250 - 279.

Hasebur, R., \& Sheikh, M. N. (2014). A comparative study of motivating potential score of employees of public and private commercial banks: An assessment of demographics influence. Global Journal of Management and Business Research, 14(4), 59-78

Herzberg, F., Mausner, B., \& Snyderman, B. B. (1959). The motivation to work (2nd ed.). New York: John Wiley and Sons

Humphrey, S. E., Nahrgang, J. D., \& Morgeson, F. P. (2007) Integrating motivational, social, and contextual work design features: A meta-analytic summary and theoretical extension of the work design literature. Journal of Applied Psychology, 92, 1332-1356.

Kariuki, N., \& Makori, M. (2015). Role of job design on employee engagement in private universities in Kenya: a case of Presbyterian university of East Africa. The Strategic Business and Change Journal of Management, 2(60), 365-385

Kemboi, A., Biwott, G., Chenuos, N., \& Rutto, A. (2013). Skill variety, feedback and employee performance: A case of Moi teaching and referral hospital Eldoret. European Journal of Business and Management, 5(19), $151-155$

Kiiza, P., \& Picho, E. O. (2015). Delegation and staff commitment in the school of finance and banking, Kigali, Rwanda, Makerere Journal of Higher Education, 7(2), 3 -13.

Kónya, V., Matić, D., \& Pavlović, J. (2016). The influence of demographics, job characteristics and characteristics of organizations on employee commitment. Acta Polytechnica Hungarica, 13(3), 119-138.

Krejcie, R. V., \& Morgan, D. W. (1970). Determining sample size for research activities. Educational and Psychological Measurement, 30, 601-610

Lawler, E. E. (2003). Pay and organizational effectiveness. A psychological review. New York: McGraw hill. New York: McGraw Hill

Livingston, S. A. (2018). Test Reliability-Basic Concepts. Princeton, NJ: Educational Testing Service.

Lunenburg, F. C. (2013). Motivating by enriching jobs to make them more interesting and challenging. International Journal of Management, Business, and Administration, 15(1), 1-11.

Lynton, R. P., \& Pareek, U. (2000). The Human Development Handbook, London, UK: Kogan Page Limited

Magaji, N. (2015). Effect of job enrichment on employee motivation in selected private universities in Southwest Nigeria. Journal of Arts, Science and Commerce, 6(4), 67

Magaji, N., Akpa, V. O., \& Akinlabi, B. H. (2017). Assessment of the effect of job enrichment on employee commitment in selected private universities in South-West Nigeria. Funai Journal of Accounting, Business and Finance (FUJABF), 1(1), 262-271,

Mone, E. M., \& London, M. (2010). Employee engagement, through effective performance management, a 
practical guide for managers. New York: Routledge

Noor Harun, A. K. (2010). The impact of work related variables on librarians' organizational commitment and job satisfaction. Malaysian Journal of Library and Information Science, 15(3), 149-163.

Moussa, M. N. (2016). Investigating the high turnover of Saudi nationals versus non-nationals in private sector companies using selected antecedents and consequences of employee engagement. International Journal of Business \& Management, 8(18).

Naqvi, S., Ishtiaq, M., Kanwal, N., \& Ali, M. (2013). Impact of job autonomy on organizational commitment and job satisfaction: The moderating role of organizational culture in fast food sector of Pakistan. International Journal of Business and Management; 8(17), 92-102.

National Universities Commission [NUC]. (2018). List of approved universities. Retrieved from https://www.nigerianinfopedia.com/nuc-list-of-approved-universities-in-nigeria

Nunnally, J. C. (1978). Psychometric theory (2nd ed.). New York: McGraw-Hill.

Nyabundi, G. O., \& Kagiri, A. (2016). Effects of task identity on the performance of employees of the Supreme Court of Kenya. International Journal of Management and Commerce Innovations, 4(2), 921-925.

Nzewi, H. N., Chiekezie, O. M., Ekene, O., Raphael, A. E., \& Ebuka, A. A. (2017). Job enrichment and employee commitment in selected brewing firms in Anambra State. Saudi Journal of Business and Management Studies, 2, 330-337.

Obi-Nwosu, H., Joe-Akuune, C. O., \& Oguegbe, T. M. (2013). Job characteristics as predictors of organization commitment among private workers in Anambra State. International Journal of Asian Social Science, 3(2), 482-491

Okebukola, P. A. (2015). Higher education and Africa's future: Doing what is right. 10th Convocation Lecture of Covenant University, Ota, June 25, 2015.

Okojie, J. A. (2016) Quality Assurance and the Challenges of Mandate Delivery in Nigerian Universities. Lecture delivered at the 18th Convocation Ceremony of Lagos State University, Lagos, February 19 th.

Oludeyi, O. S. (2015). A review of literature on work environment and work commitment: implication for future research in citadels of learning (Master's thesis). The Department of Adult Education, the University of Ibadan, Oyo State, Nigeria

Omid, M. K., \& Alborz, G. (2015). Study of the relation between job characteristics (task significance and task identity) and organizational learning. Research Journal of Fisheries and Hydrobiology, 10(13), 88-94

Ortiz, D. A., \& Lau, W. K. (2011). The effect of employee engagement on continuance and normative commitment to the organization. Paper presented at Southwest Decision Sciences Institute 42nd Annual Conference, Houston, TX.

Oyelere, M., Opute, J., \& Akinsowon, P. (2015). Organizational commitment among employees. A developing nation perspective: the case of the Nigeria's public sector. Regent's Working Papers in Business and Management, 1-59.

Pee, L. G. (2011). Effects of job design on employees' knowledge contribution. Thirty Second International Conference on Information Systems, Shanghai, Japan.

Salau, O. P., Adeniji A. A., \& Oyewunmi, A. (2014). Relationship between elements of job enrichment and organizational performance among the non-academic staff in Nigeria public universities. Marketing and Management, 23(2), 173-189.

Saragih, S. (2011). The effects of job autonomy on work outcomes: Self efficacy as an intervening variable. International Research Journal of Business Studies, 4(3), 203-215.

Shahid, A., \& Azhar, S. M. (2013). Gaining employee commitment: linking to organizational effectiveness. Journal of Management Research, 5(1), 250-268.

Sisodia, S., \& Das, I. (2013) Effect of job autonomy upon organizational commitment of employees at different hierarchical level. Psychological Thought, 6(2), 1-34.

Spector, P. E. (1986). Perceived control by employees: a metal-analysis of studies concerning autonomy and participation at work. Human Relations, 39(11), 1005-1016.

Stebbins, R. A. (1970). On misunderstanding the concept of commitment: A theoretical clarification. Social Forces, 48(4),526-529.

Steger, M. F., Littman-Ovadia, H., Miller, M., Menger, L., \& Rothmann, S. (2012). Engaging in work even when it is meaningless: positive affective disposition and meaningful work interact in relation to work engagement, Journal of Career Assessment, 21(2), 348-361.

Umoh, G. I., Mamn, E. A., \& Mnim, I. H. W. (2014). Employee benefits and continuance commitment in the Nigerian manufacturing industry. Journal of Business and Management, 16(2), 69-74.

Ushie, E. M., Agba, A. M. O., \& Okorie, C. (2015). Work environment and employees' commitment in AgroBased industries in Cross River State, Nigeria. Global Journal of Human-Social Science: Sociology \& Culture, 15(6), 9-15.

Velnampy, T., \& Sivesan, S. (2012). Determinants of employees' job satisfaction: A study of banking industries 
in Sri Lanka. Global Journal of Management and Business Research, 12(22), 342-356.

Vijay, M. V., \& Indradevi, R. (2015). A study on job enrichment and individual performance among faculties with special reference to a private university. Mediterranean Journal of Social Sciences, 6(1), 252-260.

Volmer, J., Spurk, D., \& Niessen, C. (2012). Leader-member exchange (LMX), job autonomy, and creative work involvement. The Leadership Quarterly, 23, 456-465.

Wang, C. L., Indridasson, T., \& Saunders, M. N. K. (2011). Affective and continuance commitment in public private partnership. Employee Relations, 32(4), 396-417.

Zikmund, W. G., Babin, J., Carr, J., \& Griffin, M. (2012). Business Research Methods: with Qualtrics Printed Access Card. Cengage Learning

Zopiatis, A., Constanti, P., \& Theocharous, A. L. (2014). Job involvement, commitment, satisfaction and turnover: Evidence from hotel employees in Cyprus. Tourism Management, 41, 129-140.

Appendix I

Multiple Regression Analysis Results for job-characteristics dimensions and employee continuance commitment

(a) Model 1
Model Summary

Aquare $\quad$ Adjusted R Square
.506
Std. Error of the Estimate .64744

a. Predictors: (Constant), Job Characteristics (Feedback, Skill Variety, Task Identity, Task Significance, Autonomy)

Source: Field Survey, 2018

\begin{tabular}{|l|l|c|c|c|c|c|}
\hline \multicolumn{2}{|c|}{ (b) } & \multicolumn{1}{l|}{ ANOVA } \\
\hline \multicolumn{2}{|l|}{ Model } & Sum of Squares & Df & Mean Square & F & Sig. \\
\hline \multirow{3}{*}{1} & Regression & 163.648 & 5 & 32.730 & 78.081 & $.000^{\mathrm{b}}$ \\
\cline { 2 - 7 } & Residual & 155.513 & 371 & .419 & & \\
\cline { 2 - 7 } & Total & 319.161 & 376 & & & \\
\hline
\end{tabular}

a. Dependent Variable: Employee Continuance Commitment

b. Predictors: (Constant), Job Characteristics (Feedback, Skill Variety, Task Identity, Task Significance, Autonomy)

Source: Field Survey, 2018

\begin{tabular}{|c|c|c|c|c|c|c|}
\hline \multicolumn{2}{|c|}{ (c) } & \multicolumn{2}{|c|}{ Coefficients $^{\mathrm{a}}$} & & & \\
\hline \multirow{2}{*}{\multicolumn{2}{|c|}{ Model }} & \multicolumn{2}{|c|}{$\begin{array}{c}\text { Unstandardized } \\
\text { Coefficients }\end{array}$} & \multirow{2}{*}{$\begin{array}{c}\begin{array}{c}\text { Standardized } \\
\text { Coefficients }\end{array} \\
\text { Beta } \\
\end{array}$} & \multirow[t]{2}{*}{$\mathbf{T}$} & \multirow[t]{2}{*}{ Sig. } \\
\hline & & B & Std. Error & & & \\
\hline \multirow[t]{6}{*}{1} & (Constant) & -.858 & .328 & & -2.615 & .009 \\
\hline & Skill Variety & -.138 & .077 & -.088 & -1.783 & .075 \\
\hline & Task Identity & .207 & .091 & .118 & 2.286 & .023 \\
\hline & Task Significance & .249 & .085 & .158 & 2.932 & .004 \\
\hline & Autonomy & .184 & .095 & .119 & 1.934 & .064 \\
\hline & Feedback & .578 & .071 & .474 & 8.163 & .000 \\
\hline
\end{tabular}

a. Dependent Variable: Employee Continuance Commitment

Number of respondents: 377

Level of significance $0.05(5 \%)$

Significant at $\mathrm{p}<0.05$ 